12. Шапарь В.П. Словарь практичного психолога / В.Б. Шапарь. - М.: ООО "Издательство АСТ"; Х.: "Торсинг", 2004. - 734 с.

\title{
References
}

1. Andreeva, G. M. Social'naja psihologija : ucheb. dlja vuzov / Galina Mihajlovna Andreeva. - M. : Aspekt Press, 1998. - 376 s.

2. Giddings G. The Theory of Socialization. - 1897. - №. 8. - P. 22

3. Honcharenko S.U. Ukrainskyi pedahohichnyi slovnyk / S.U. Honcharenko. - K.: Lybid, 1997. - 376 s. S. 314

4. Gur'janova M. P. Sel'skaja shkola i social'naja pedagogika: Metod. posob. - Mn.: Amalgfeja, 2000. S. $249-250$

5. Zakon Ukrainy "Pro molodizhni ta dytiachi hromadski orhanizatsii" // Uriadovyi kur'ier. - 1999. - 12 sichnia. - № 4. - S. 10

6. Kovbas B. I. Pidhotovka maibutnoho vchytelia do roboty z tymchasovymy obiednanniamy : dys. ... kand. ped. nauk : 13.00.01 / Bohdan Ivanovych Kovbas; Naukovo-metodychnyi tsentr "Ukrainska etnopedahohika i narodoznavstvo" APN i Prykarpatskoho universytetu im. Vasylia Stefanyka. Ivano-Frankivsk, 1998. S. 28-29

7. Korniievskyi O. Molodizhnyi rukh ta politychni obiednannia v suchasnii Ukraini / O. Korniievskyi, V. Yakushyk. - K. : Kyivske bratstvo, 1997. - 130 s.

8. Kostiuk H. S. Navchalno-vykhovnyi protses i psykhichnyi rozvytok osobystosti / Hryhorii Sylovych Kostiuk; za red. L.M. Prokoliienko. - K. : Radianska shkola, 1989. - 608 s. S. 272-274

9. Lavrychenko N. M. Pedahohika sotsializatsii: yevropeiski abrysy / N. M. Lavrychenko. - K. : VIRAINSAIT, 2000. - 444 s. S. 31

10. Orban-Lembryk L.E. Sotsialna psykholohiia: posibnyk / L.E. Orban-Lembryk. - K.: Akademvydav, 2003. - 448 s.

11. Polishchuk Yu. Y. Sotsializatsiia molodi u konteksti diialnosti hromadskykh molodizhnykh ob'iednan / Yu. Y. Polishchuk // Aktualni problemy profesiinoi pidhotovky fakhivtsiv sotsialnoi roboty v Ukraini ta za rubezhem : materialy mizhn. nauk.-prakt. konf-i 5-6 travnia 2003 roku. Uzhhorod, 2003.

12. Shapar' V.P. Slovar' praktichnogo psihologa / V.B. Shapar'. - M.: OOO "Izdatel'stvo AST"; H.: "Torsing", 2004. - $734 \mathrm{~s}$.

Одержано статтю: 27.06.2019

Прийнято до друку: 11.07.2019

УДК: $37.064 .1 .035: 316.752-053.6$

DOI: $10.15330 /$ esu. $16.143-150$

\section{Любов Каніневська,}

доктор педагогічних наук, професор, Інститут проблем виховання НАПН України (м. Київ, Україна)

Liubov Kanishevska, Doctor of pedagogical sciences, Professor, Institute of Problems on Education of the NAES of Ukraine (Kyiv, Ukraine) mazila060192@ukr.net

\section{ФОРМУВАННЯ БЕЗПЕКИ ЖИТТЯ У СТАРШОКЛАСНИКІВ}

\section{FORMING OF LIFE SAFETY AMONG HIGH SCHOOL STUDENTS}

У статті визначено та схарактеризовано фактори, що ускладнюють прочес формувания безпеки життя у стариокласників: вплив групи; особливості емочійної сфери; потреба в сочіальному визнанні i факті дорослімання; віддаленість від батьків; доступність, популяризачія тютюнових, алкогольних, наркотичних речовин через рекламу; негативний вилив молодіжної субкультури; потреба у прояві власної індивідуальності та неможливості ї задовольнити; спадковість; сімейне неблагополуччя тощо. Визначено иляхи формувания безпеки життя у зазначеного контингенту иколярів, а саме: 
розробления та впроваджения у позаурочну діяльність закладів загальной середньої освіти авторської програми "Збережи себе сам"; залучення стариокласників до здоров'язбережувальної діяльності, спрямованої як на формувания, збереження і змічнення власного здоров'я, так і здоров'я іниих; педагогічна підтримка стариокласників.

Ключові слова: безпека, небезпека, безпека життя, стариокласники; здоров'язбережувальна діяльність.

The article is devoted to the essence of the concept of "safety of life" as a human activity which is determined by the necessary knowledge and skills in order to prevent and overcome dangerous and harmful situations; it is based on a system of social norms, beliefs and values that ensure the preservation of life, human health and the integrity of the surrounding world. The factors that complicate the process of formation of safety of life among high school students are divided into: influence of the group; features of the emotional sphere; the need for social recognition and the fact of maturation; distance from parents; accessibility, popularization of tobacco, alcohol, narcotic substances through advertising; negative influence of youth subculture; the need for manifestation of one's own personality and impossibility of satisfying it; heredity; family problems, etc.

The ways of formation of safety of life among high school students have been determined. Firstly, the author develops the program "Save Yourself" for extracurricular activities of institutions of general secondary education. The tasks of the program are to form safety of life among high school students as a component of the value of life; to develop healthy lifestyles among high school students; to develop the ability to withstand the pressure from other people; the ability to make an adequate choice and to be responsible for it; the ability to self-knowledge and self-education. This program is implemented through the following forms of organization of extracurricular activities for the formation of safety of life among high school students: lessons with elements of training, educational hours, conversations, discussions, problem dialogues and meditations, quizzes, projects, events, etc. Secondly, high school students are involved in healthsaving activities, which are aimed at forming, preservation and strengthening of their own health, as well as the health of others through the students' self-government. Thirdly, there is a pedagogical support for high school students. Teachers should express pedagogical optimism; focus on dialog and non-violent communication in the process of organizing interaction between teachers and high school students based on pedagogical support.

Key words: safety, danger, safety of life, high school students; health-saving activity.

Постановка проблеми у загальному вигляді та їі зв'язок із важливими науковими чи практичними завданнями. Формування безпеки життя - один із пріоритетних напрямів сучасного виховання, про що свідчить зміст держаних документів: Конституція України, Закони України "Про охорону дитинства", “Про освіту”, Національна стратегія розвитку освіти в Україні на період до 2021 року, “Нова українська школа у поступі до цінностей”, розділ звіту ООН “Нові вимоги до безпеки людини” та ін.

Особливої актуальності набуває проблема формування безпеки життя у старшокласників, оскільки рання юність становить групу підвищеного ризику. Поперше, даються взнаки внутрішні труднощі перехідного віку, починаючи 3 психогормональних процесів та закінчуючи перебудовою Я-концепщії. По-друге, суміжність та невизначеність соціального стану юнацтва. По-третє, суперечності, що обумовлені перебудовою механізмів соціального контролю: дитячі форми контролю, шо засновані на додержанні зовнішніх норм і слухняність по відношенню до дорослих уже не діють, а дорослі засоби, що передбачають свідому дисципліну та самоконтроль, ще не склалися та не зміцніли [9, с. 175]. 
Аналіз останніх досліджень і публлікацій. Різні аспекти формування безпеки життя в учнівської молоді знайшли відображення в працях соціологів (О. Балакірєва, О. Віцько та ін.), криміногологів (В. Пшеничний, Л. Раєцька, , М. Хруппа); медиків (В. Беспалько, С. Ваїсов та ін.); наркологів (Д. Колесов, Ц. Короленко, П. Сидоров та ін.); психологів (І. Бех, С. Болтівець, С. Максименко, Н. Максимова та ін.); педагогів (О. Безпалько, . Звєрєва, Н. Зимівець, А. Капська, О. Карпенко, О. Лящук, В. Оржеховська, О. Пилипенко, Н. Пихтіна, Т. Федорченко та ін.).

Незважаючи на проведені дослідження, проблема формування безпеки життя старшокласників як складника цінності життя не була предметом спеціального дослідження.

Мета статті - схарактеризувати фактори, що ускладнюють процес формування безпеки життя у старшокласників та визначити шляхи формування безпеки життя у зазначеного контингенту школярів.

Виклад основного матеріалу. У довідкових виданнях поняття "безпека" визначається як відсутність небезпеки, надійність; ототожнюється 3 поняттям “національна безпека".

Загальна теорія безпеки, об'єктом і предметом дослідження якої є діяльність людей та забезпечення власної безпеки та безпеки умов життя, створюється завдяки зусиллям вчених природничих, суспільних та технічних наук, тобто $є$ продуктом міждисциплінарних комплексних досліджень [5, с. 17].

Центральним поняттям теорії безпеки є “безпека” та протилежне йому поняття "небезпека".

Небезпека - це явища, процеси, об'єкти, здатні завдавати шкоди здоров'ю людини безпосередньо або побічно (наприклад, унаслідок погіршення стану навколишнього середовища). Варто розрізняти: техногенно-виробничі небезпеки, обумовлені господарською діяльністю; природно-екологічні небезпеки, обумовлені причинами природничого характеру; соціально-економічні небезпеки, обумовлені причинами соціального, економічного i психологічного характеру; військові небезпеки, обумовлені військовими діями, роботою військово-промислового комплексу, терористичними актами [1].

Уточнено сутність поняття “безпека життя" як діяльності людини, що визначається необхідними знаннями та навичками 3 профілактики та подолання небезпечних та шкідливих ситуацій, заснована на системі соціальних норм, переконань і цінностей, що забезпечують збереження життя, здоров'я людини та цілісності оточуючого світу.

Основним новоутворенням підліткового та раннього юнацького віку $є$ почуття дорослості. І. Бех доводить, що першим і основним показником цього почуття $\epsilon$ виникнення в вихованця потреби у ставленні до нього як до дорослого. У разі ігнорування цієї потреби педагогом, вихованці виявляють образу, різні форми протесту: неслухняність, грубість, упертість, протиставлення себе дорослим чи товаришам, зіткнення й конфлікти. Другим показником почуття дорослості, зазначає I. Бех, є прагнення до самостійності та бажання захистити деякі сфери свого життя від утручання дорослих. Третій показник наявності у підлітків почуття дорослості вироблення власної лінії поведінки, іноді всупереч дорослим чи товаришам [3, c. 116-117].

Особливе занепокоєння викликають тенденції зростання серед молодого покоління схильності до небезпечної поведінки.

Із 90-х років минулого століття число наркозалежних в Україні щорічно 
збільшується на 10-12\%, із цієї кількості на дорослих припадає тільки $27 \%$, тоді як на підлітків - 60\%, а на дітей у віці від 11 до 14 років - 13\%. Середній вік наркоспоживача в Україні щороку знижується на 0,1-0,15 року. За останні п'ять років кількість споживачів наркотиків серед дітей і підлітків у віці до 16 років збільшилася на $45 \%$, у тому числі кількість таких неповнолітніх із діапазоном наркозалежності збільшилася на $25 \%$ [12, с. 29].

Серед молоді найбільш популярними $є$ слабоалкогольні напої, до яких належить пиво, лонгер, ром-кола, джин-тонік, медові хмельні напої. Одним із негативних явищ $є$ хвороблива пристрасть до пива (пивний алкоголізм). За останні десять років пивних алкоголіків в Україні стало вдесятеро більше. Сьогодні 1\% дітей 12-13 років щодня вживають алкогольні напої [13].

Схарактеризуємо фактори, що ускладнюють процес формування безпеки життя у старшокласників. До біологічних факторів відносимо спадковість.

Дослідники В. Бітенський, Б. Херсонський, С. Дворняк стверджують, що фетальний алкогольний синдром, окрім специфічних фізичних вад, супроводжується ще і постнатальним ураженням нервової системи. Часто він виявляється у вигляді психоподібних та психопатичних проявів. Усе це ускладнює або унеможливлює соціальну адаптацію, зменшує захисну реакцію організму на психоактивні речовини [4, с. 31-38]. Така залежність формується при регулярному вживанні психоактивних речовин [11]. Таким чином, при правильно організованому вихованні дітей, чиї батьки є алкоголіками і наркоманами, мінімізується ступінь ризику формування залежності від психоактивних речовин.

Одним із факторів, що ускладнює процес формування безпеки життя у школярів виступають акцентуації характеру та психопатії.

Психопатії - виражені характерологічні порушення, відмінними особливостями яких $є$ тотальність, відносна стабільність і соціальна дезадаптація. Саме останній критерій $\epsilon$ вирішальним для диференціації акцентуацій i психопатій. Психопати $\epsilon$ особливо схильними до небезпечної поведінки. За узагальненими даними різних авторів серед алкоголезалежних близько 50\% людей страждає на психопатію, на наркоманію - близько $35 \%$. Найбільш уразливі до вживання психоактивних речовин мають нестійкий, гіпертимний, циклоїдний, епілептоїдний, збудливий, істероїдний типи акцентуацій характеру [11, с. 75-76].

Одним із соціальних факторів, що ускладнює процес формування безпеки життя у старшокласників, $\epsilon$ негативний вплив молодіжної субкультури, яка неоднозначно впливає на молодь. 3 одного боку, вона $\epsilon$ одним із інструментів соціалізації, сприяє опануванню цінностей і соціальних ролей, а з іншого, - відчужує молодь від загальної культури. Проблеми виникають тоді, коли “інтереси та цінності молодого покоління обмежені сферою дозвілля, розважальними заходами, часто спілкування з делінквентним оточенням однолітків" [10, с. 38].

Дослідник А. Худяков зазначає, що для юнаків та юнок специфічним є адаптивний фактор вживання психоактивних речовин - для входження в референтну групу й утримання в ній - $\epsilon$ неадаптивний фактор - для відходу від конфлікту (“3 горя”, для зняття напруги, для самоствердження тощо) [15, с. 8-10].

Наступним фактором, що значно ускладнює процес формування безпеки життя у старшокласників, є доступність, популяризація тютюнових, алкогольних, наркотичних речовин через рекламу. Це $\epsilon$ однією з основних причин популярності вживання психоактивних речовин у молодіжному середовищі. 
Іншим соціальним фактором, що ускладнює процес формування безпеки життя у школярів, є подвійна мораль, що “... міцно вкорінилася в усіх соціальних сферах і є каменем спотикання в розвитку особистості" [10, с. 37$]$.

Пристаємо до думки дослідників М. Максимової, С. Толстоухової, які зазначають, що подвійна мораль згубно впливає на психіку юнаків та юнок, формує в них почуття ущербності, яке переходить у комплекс неповноцінності. Цей комплекс людина часто “приглушує” за допомогою вживання шкідливих речовин $[11$, c. 55].

Домінантною соціальною умовою, що ускладнює процес формування безпеки життя у старшокласників, є негативний вплив сім’ї, оскільки сімейне неблагополуччя сприяє розвитку емоційних відхилень і на їх основі різноманітних соціальних відхилень, у тому числі й небезпечної поведінки. Конфліктні стосунки між батьками, пияцтво батьків, вживання ними наркотиків згубно впливає на дитину.

Наступним фактором, що ускладнює процес формування безпеки життя у старшокласників, є негативний соціально-психологічний статус в колективі, під яким мається на увазі “несприйнятлива позиція суб'єкта в системі міжособистісних стосунків, що визначає його право, обов'язки та привілеї” [10, с. 41]. Статус юнака у групі істотно впливає на його самосвідомість і поведінку. Несприятливе положення в колективі є причиною того, що учень уникає спілкування з однолітками, унаслідок цього з'являються прогули, які $є$ однією з перших ознак проблем соціалізації. Часто школяр потрапляє під негативний вплив неформальної групи [14, с. 80-85].

Пристаємо до думки Н. Максимової, С. Толстоухової, що негативний вплив на психіку юнаків має і так зване альтернувальне виховання, тобто - нестійке емоційне ставлення до школяра, коли схвалення або нарікання залежать від настрою дорослих, а не від об'єктивної поведінки учня. Унаслідок цього вихованець відмовляється від спроб зрозуміти причинно-наслідкові зв'язки оточуючого соціуму, не аналізує відповідність своїх учинків соціальним нормам, не вникає в причини зміни свого настрою. Подорослішавши, людина для підняття настрою вдається до штучних способів регулювання психічного стану, серед яких - алкоголь, тютюн, наркотичні речовини тощо [11].

Слід зазначити, що часто "нещасливе кохання" може провокувати старшокласників до куріння, зловживання алкоголем, наркотиками, токсичними речовинами.

Ще одним важливим фактором, що ускладнює процес формування безпеки життя у старшокласників, може бути потреба у прояві власної індивідуальності і неможливість їі задовольнити. Невдачі у навчанні, негативний статус юнака в групі однолітків, непорозуміння 3 батьками, вчителями призводить до виникнення в старшокласників психологічного дискомфорту, що змушує їх шукати нове середовище асоціальної спрямованості. У такій ситуації юнаки проявляють демонстративну поведінку, яка може виявлятися у зовнішньому вигляді та манері вдягатися, спрямованої на підкреслення своєї незалежності; а також часто відзначається зловживанням алкоголем, палінням, а іноді й наркотичними, токсичними речовинами.

Таким чином, визначено та схарактеризовано фактори, що ускладнюють процес формування безпеки життя у старшокласників: вплив групи; особливості емоційної сфери; потреба в соціальному визнанні і факту дорослішання; віддаленість від батьків; доступність, популяризація тютюнових, алкогольних, наркотичних речовин через рекламу; негативний вплив молодіжної субкультури; потреба у прояві власної індивідуальності та неможливості їі задовольнити; спадковість; сімейне неблагополуччя тощо. 
Визначено шляхи формування безпеки життя у старшокласників, серед яких:

1. Розроблення та впровадження у позаурочну діяльність закладів загальної середньої освіти авторської програми "Збережи себе сам". Завдання програми: формування безпеки життя у старшокласників як складника цінності життя; формування у старшокласників здорового способу життя; вміння протистояти тиску з боку інших людей; вміння робити адекватний вибір і нести за нього відповідальність; здатності до самопізнання та самовиховання. Ця програма реалізовується за допомогою наступних форм організації позаурочної діяльності з формування у старшокласників безпеки життя: заняття 3 елементами тренінгу, виховні години, бесіди, дискусії, проблемні діалоги-роздуми, вікторини, проектна діяльність, акції тощо.

2. Залучення старшокласників до здоров'язбережувальної діяльності, спрямованої як на формування, збереження і зміцнення власного здоров'я, так і здоров'я інших, що реалізується в рамках учнівського самоврядування [8, с. 238]. Разом iз тим не можна забувати, що діяльність $є$ лише потенційним вихователем. Вона може формувати корисні якості, може бути нейтральним процесом i, насамкінець, здатна за певних умов не розвивати, а деформувати вихованця як особистість. Вирішальну роль тут відіграє правильна організація діяльності, яка детермінується рівнем педагогічної майстерності педагогів [6, с. 96].

Здоров'язбережувальна діяльність закладів середньої освіти включає наступні iї форми і види:

1) систему корекції порушень соматичного здоров'я з використанням комплексу оздоровчих і медичних заходів;

2) різні форми організації освітнього процесу з урахуванням його психологічного й фізіологічного впливу на організм;

3) контроль за дотриманням санітарно-гігієнічних норм організації освітнього процесу, нормування навчального навантаження і профілактики втомлюваності учнів;

4) систему медико-психологічних, гігієнічних методик моніторингу стану здоров'я і профілактики шкідливих звичок;

5) розробку i реалізацію навчальних програм щодо формування культури здоров'я і профілактики шкідливих звичок;

6) службу психологічної допомоги вчителям і учням у плані подолання стресів, тривожності, сприяння гуманного підходу до кожної дитини, формування доброзичливості і справедливих відносин у колективі;

7) заходи, спрямовані на зміцнення здоров'я учнів, створення умов для їх гармонійного розвитку [2, с. 122-123].

3. Педагогічна підтримка старшокласників. Здійснюючи педагогічну підтримку учнів, педагоги мають стимулювати у вихованців самопізнання своїх позитивних рис; формувати моральні якості школяра у процесі оцінювання власної поведінки; акцентувати увагу на позитивних вчинках учнів; підтримувати ініціативу, активність; виявляти довіру до вихованців; формувати у школярів віру у власні сили [7, с 219].

Висновки. Визначено фактори, що ускладнюють процес формування безпеки життя у старшокласників закладів загальної середньої освіти та визначено шляхи формування безпеки життя у зазначеного контингенту школярів. Проведене дослідження не вичерпує багатогранності теоретичних $\mathrm{i}$ практичних пошуків розв'язання проблеми. Подальшого вивчення і розвитку потребують такі питання, як формування безпеки життя у вихованців різних вікових груп (молодші школярі, 
молодші підлітки); використання потенціалу позаурочної діяльності у контексті досліджуваної проблеми.

Лiтература
1. Безпека [Електронный ресурс]. - Режим доступа : http : //nuczu.edu.ua/files/books/ bezpeka_gitted/bezpeka_gitted\%2014.pdf

2. Безруких М. М. Здоровьесберегающая школа / М. М Безруких. - М. : Московский психологосоциальный институт, 2004. - $240 \mathrm{c}$.

3. Бех І. Д. Виховання особистості: [у 2-х кн.] - Кн. ІІ. : Особистісно орієнтований підхід: науково-практичні засади / І. Д. Бех. - К. : Либідь, 2003. - 344 с.

4. Битенский В. С. Наркомания у подростков. / В. С. Битенский, Б. Г. Херсонский, С. В. Дворяк и др. - К. : Здоровье, 1989. - 216 с.

5. Данченко С. П. Практикум в курсе "Основы безопасности жизнедеятельности" как условие адаптации учащихся к экстремальным ситуациям : дисс. ... канд. пед наук / С. П. Данченко. Санкт -Петербург, 2004. - 168 с.

6. Канішевська Л. В. Підготовка старшокласників шкіл-інтернатів до життєдіяльності у відкритому суспільстві (вихідні концептуальні положення) / Л. В. Канішевська // Теоретикометодичні проблеми виховання дітей та учнівської молоді : зб. наук. праць. Кам'янецьПодільський, 2011. - Вип. 15. - Кн 2. - С. 88-97.

7. Канішевська Л. В. Дослідження проблеми виховання соціальної зрілості старшокласників шкіл-інтернатів / Л. В. Канішевська. // Педагогічний альманах : зб. наук. праць. Херсон КВНЗ "Херсонська академія неперервної освіти", 2012. - Вип. 16. - С. 213-220.

8. Kanishevska Liubov. The formation of the immunity to the use of psychoactive substances by senior teenagers as the tendency of the formation of the life safety / Liubov Kanishevska. // Topical is sueso feducation: Collective monograph. - Pegasus Publishing, Lisbon, Portugal, 2018. P. 231-243.

9. Кон И. С. Психология старшеклассника / И. С. Кон. - М. : Просвещение, 1982. - 207 с.

10. Лящук О. С. Профілактика шкідливих звичок в учнів 5-6 класів шкіл-інтернатів у позаурочній діяльності: дис. ... канд. пед. наук: спец. 13.00.07 "Теорія і методика виховання" / О. С. Лящук. - Умань, 2017. - 246 с.

11. Максимова Н. Ю. Соціально-психологічний аспект адиктивної поведінки підлітків та молоді. / Н. Ю. Максимова, С. В. Толстоухова. - К., 2000. - 200 с.

12. Оржеховська В. М. Формування здорового способу життя: стратегія розвитку / В. М. Оржеховська // Науковий світ. - 2008. - № 10. - С. 28-30.

13. Пивний алкоголізм : симптоми, ознаки, наслідки та лікування - Режим доступа : http : // hollydolly.com.ua/pivnij-alkogolizm-simptomi-oznaki-na.html

14. Подход жизненных ситуаций в профилактике табачных проблем / ред. Андреевой Т. И., Красовского К. С. - К., 2000. - Ч. 1. - 140 с.

15. Худяков А. В. Клинико-социальные аспекты формирования и профилактика зависимости от психоактивних веществ у несовершеннолетних: автореф. дис. ... д-ра. мед. наук : спец. $14.00 .45 ; 14.0018$ "Наркология", "Психиатрия" / А. В. Худяков; Ивановская государственная медицинская академия. М., 2003. - 37 с.

\section{References}

1. Bezpeka [Elektronnyij resurs]. - Rezhy'm dostupa : - Режим доступа : http : //nuczu.edu.ua/files/ books/bezpeka_gitted/bezpeka_gitted\%2014.pdf

2. Bezrukih M. M. Zdorovesberegayuschaya shkola / M. M Bezrukih. - M. : Moskovskiy psihologosotsialnyiy institut, 2004. $-240 \mathrm{~s}$.

3. Bekh I. D. Vykhovannia osobystosti: [u 2-kh kn.] -Kn. II. : Osobystisno oriientovanyi pidkhid: naukovo-praktychni zasady / I. D. Bekh. - K. : Lybid, 2003. - 344 s.

4. Bitenskiy V. S. Narkomaniya u podrostkov. / V. S. Bitenskiy, B. G. Hersonskiy, S. V. Dvoryak i dr. K. : Zdorove, 1989. - $216 \mathrm{~s}$.

5. Danchenko S. P. Praktikum v kurse "Osnovyi bezopasnosti zhiznedeyatelnosti" kak uslovie adaptatsii uchaschihsya k ekstremalnyim situatsiyam : diss. ... kand. ped nauk / S. P. Danchenko. - Sankt Peterburg, 2004. - $168 \mathrm{~s}$.

6. Kanishevska L. V. Pidhotovka starshoklasnykiv shkil-internativ do zhyttiediialnosti u vidkrytomu suspilstvi (vykhidni kontseptualni polozhennia) / L. V. Kanishevska // Teoretyko-metodychni problemy vykhovannia ditei ta uchnivskoi molodi : zb. nauk. prats. Kamianets-Podilskyi, 2011. Vyp. 15. - Kn 2. - S. 88-97 
7. Kanishevska L. V. Doslidzhennia problemy vykhovannia sotsialnoi zrilosti starshoklasnykiv shkilinternativ / L. V. Kanishevska. // Pedahohichnyi almanakh : zb. nauk. prats. Kherson KVNZ "Khersonska akademiia neperervnoi osvity", 2012. - Vyp. 16. - S. 213-220.

8. Kanishevska Liubov. The formation of the immunity to the use of psychoactive substances by senior teenagers as the tendency of the formation of the life safety / Liubov Kanishevska. // Topical is sueso feducation: Collective monograph. - Pegasus Publishing, Lisbon, Portugal, 2018. P. 231-243.

9. Kon I. S. Psihologiya starsheklassnika / I. S. Kon. - M. : Prosveschenie, 1982 - 207 s.

10. Liashchuk O. S. Profilaktyka shkidlyvykh zvychok v uchniv $5-6$ klasiv shkil-internativ u pozaurochnii diialnosti: dys. ... kand.. ped. nauk : spets. 13.00.07 "Teoriia i metodyka vykhovannia" / O. S. Liashchuk. - Uman, 2017. $-246 \mathrm{~s}$.

11. Maksimova N. Yu. SotsIalno-psihologIchniy aspekt adiktivnoYi povedInki pIdlItkIv ta molodI. / N. Yu. Maksimova, S. V. Tolstouhova. - K., 2000. $-200 \mathrm{~s}$

12. Orzhekhovska V.M. Formuvannia zdorovoho sposobu zhyttia: stratehiia rozvytku / V. M. Orzhekhovska // Naukovyi svit. - 2008. - № 10. - S. 28-30

13. Pyvnyi alkoholizm : symptomy, oznaky, naslidky ta likuvannia - Rezhym dostupa: http : // hollydolly.com.ua/pivnij-alkogolizm-simptomi-oznaki-na.html:

14. Podhod zhiznennyih situatsiy v profilaktike tabachnyih problem / red. Andreevoy T. I., Krasovskogo K. S. - K., 2000. - Ch. 1. $-140 \mathrm{~s}$.

15. Hudyakov A. V. Kliniko-sotsialnyie aspektyi formirovaniya i profilaktika zavisimosti ot psihoaktivnih veschestv u nesovershennoletnih: avtoref. dis. ... d-ra. med. nauk : spets. 14.00.45; 14.0018 "Narkologiya", "Psihiatriya" / A. V. Hudyakov; Ivanovskaya gosudarstvennaya meditsinskaya akademiya. M., 2003. -37 s.

Одержано статтю: 12.06 .2019

Прийнято до друку:26.06.2019

УДК 37013.42:37.018.265

DOI: $10.15330 /$ esu. $16.150-156$

\section{Іванна Кулик,}

кандидат педагогічних наук, доцент, ДВНЗ “Прикарпатський національний університет імені В. Стефаника" (м. Івано-Франківськ, Україна)

\section{Ivanna Kulyk,}

Candidate of pedagogical scienses $(\mathrm{PhD})$, Assosiate Proffesor, Vasyl Stefanyc Precarpathian National University (Ivano-Frankivsk, Ukraine) ivannakyluk@ukr.net

Марія Комановська, магістрантка, ДВНЗ “Прикарпатський національний університет імені В. Стефаника" (м. Івано-Франківськ, Україна)

\section{Mariia Komanovska,} master's, Vasyl Stefanyc Precarpathian National University (Ivano-Frankivsk, Ukraine) komanovska@icloud.com

\section{ФОРМУВАННЯ ПЕДАГОГІЧНОЇ КУЛЬТУРИ У СПІЛКУВАННІ МАЙБУТНІХ СОЦАЛЬНИХ ПЕДАГОГІВ 3 БАТЬКАМИ УЧНІВ У ПРОЦЕСІ ФАХОВОГО НАВЧАННЯ}

\section{FORMING OF PEDAGOGICAL CULTURE OF COMMUNICATION IN FUTURE SOCIAL PEDAGOGUES WITH PARENTS OF STUDENTS IN THE PROCESS OF STUDYING}

У статті висвітлено теоретичну підготовку майбутніх сочіальних педагогів до спілкувания з батьками учнів икіл. 